\title{
The review of selected biomarkers of abdominal aortic aneurysm
}

\author{
Stanisław Surma ${ }^{1,2}$, Marta Lesiak', Beata Dorzak², Grzegorz Bajor ${ }^{2}$ \\ 'Department of Molecular Biology and Genetics School of Medicine in Katowice, Medical University of Silesia, Katowice, Poland \\ ${ }^{2}$ Department of Human Anatomy, Faculty of Medicine, Medical University of Silesia in Katowice, Poland
}

\begin{abstract}
Abdominal aortic aneurysm (AAA) is a disease affecting the main artery transporting oxidized blood to the abdominal and pelvic organs. Abdominal aortic aneurysms occur 4-8 times more often in men than in women, usually develop after the age of 55. Among men over 65, 4-7.6\%, this diagnosis can be expected. More aneurysms occur in Caucasian people. Among the most frequently mentioned in the literature, AAA risk factors are older age, male gender, positive family history, smoking, chronic obstructive pulmonary disease, hypertension, hypercholesterolemia, peripheral arterial occlusive disease, ischemic heart disease. Biochemical tests to determine the level of AAA-specific markers appear with potential. There are reports in the literature on the possible use of concentrations of selected molecules in the diagnosis of AAA. According to cadaveric research, there are noticed dimensions of the abdominal aorta at its different levels. The relation between aortic size and shape can be the factor contributing to the development of AAA. Previous studies have shown that the development of AAA is a crucial fundamental inflammatory response in conjunction with proteolysis tissue, which causes the destruction and reconstruction of the blood vessel wall. Numerous factors contribute to the pathogenesis of AAA: proteins, transcription factors, enzymes and microRNAs. The increase in the concentration of most factors is associated with inflammation. The biomarkers presented in the paper are not limited to AAA, and thus can be used only for visual assessment of the degree of abdominal aortic aneurysm development.
\end{abstract}

Key words: abdominal aortic aneurysm, AAA-specific markers, inflammation, risk factors, biomarkers

Acta Angiol 2019; 25, I: 19-27

\section{Introduction}

An abdominal aortic aneurysm (AAA) is a local dilatation above $30 \mathrm{~mm}$ of the vessel diameter located below the renal arteries [ $1-3]$. Widening of the aorta is usually bag-shaped, less sparse fusiform [4]. Widening of the abdominal aorta above $50 \mathrm{~mm}$ is a significant clinical problem because there is a high risk of its rupture, which is a direct threat to a patient's life [5]. The indication for AAA surgery is the vessel diameter exceeding $55 \mathrm{~mm}$, symptomatic or ruptured.

Epidemiological data indicate that AAA occurs in $4.4 \%$ of the population age of 40 years and older.
This disease mainly affects men, in whom it is 3 to 8 times more frequent than in women. Among the population aged $60-65$, AAA suffers from $3 \%$ of men. AAA occurs in $9 \%$ of men over 75 years of age. [6]. In the recent 20 years, the number of AAAs cases increased due to the ageing of the population and to the increase in the early detection of this condition. Very often, the first symptom of AAA is its rupture. Some $40 \%$ of patients die from unrecognized AAA [7]. AAA is the cause of $1-3 \%$ of deaths in the population aged between 65 and 85 years in economically developed countries. Very rarely, aneurysms are diagnosed in children [8].

Address for correspondence: Marta Lesiak, Department Of Molecular Biology and Genetics School of Medicine in Katowice Medial University of Silesia, Medyków 18, CI/IV p., 40-752 Katowice, Poland, e-mail: mlesiak@sum.edu.pl 
Table I. Selected AAA biomarkers

\begin{tabular}{|l|c|c|}
\hline Biomarker & Structure & Reference \\
\hline Homocysteine & Amino acid & {$[\mathrm{II}]$} \\
\hline Osteoprotegerin & Protein & {$[12]$} \\
\hline Osteopontin & Protein & {$[12]$} \\
\hline miRNA7I2/205 & & {$[13,14]$} \\
miRNA 29c-3p & Micro RNA & {$[15]$} \\
\hline Interleukins: 2, 6, 10 & Proteins & {$[15]$} \\
\hline C-reactive proteins (CRP) & Protein & {$[16]$} \\
\hline$\alpha_{1}$-antiproteinase & Protein & {$[16]$} \\
\hline antithrombin III (AT-III) & Protein & {$[16$} \\
\hline Cystatin C & Protein & {$[17]$} \\
\hline ELFI, ETS2, RUNXI, STAT5 & Proteins & {$[18]$} \\
\hline Metalloproteinases: MMP-2, MMP-3, MMP-9, MMP-I4 & & Transcription factors, proteins \\
\hline
\end{tabular}

There are three main types of AAA: (I) asymptomatic, (II) symptomatic and (III) cracked. An additional type of AAA is an inflammatory aneurysm representing about $10 \%$ of the cases. Another AAA classification constitutes such categories as: (I) due to the etiology - atherosclerotic, degenerative syndrome (Marfan syndrome, Ehlers and Danlos syndrome type IV, aortic cyst degeneration), post-inflammatory (Takayasu disease, giant cell arteritis, systemic inflammation, syphilis, endocarditis, sepsis) and post-traumatic; (2) due to the shape of AAA - a baggy (usually in the subclavian artery of the left or the lower wall of the aortic arch), fusiform (much more frequent); (3) due to the construction of the wall - true, alleged (the wall creates adventitia with surrounding tissues after the internal and middle membrane is disrupted, most often post-traumatic); (4) due to the clinical pattern - asymptomatic, symptomatic, and broken and (5) due to the location - thoracic (usually ascending aorta), abdominal (below the diaphragm, aneurysm in the subrenal section constitute $\sim 90 \%$ of aortic aneurysms), thoraco-abdominal [9].

At the symptomatic stage, the risk of rupture of the abdominal aortic aneurysm within 5 years is $2 \%$ with a diameter of $<40 \mathrm{~mm}, 3$ to $12 \%$ with a diameter of 40 to $50 \mathrm{~mm}, 25$ to $40 \%$ with a diameter of $>50 \mathrm{~mm}$ [9]. Mortality due to AAA rupture is estimated at about 40 to $60 \%$. Usually, AAA is detected accidentally, for example during an ultrasound examination. Biochemical tests to determine the level of AAA-specific biomarkers seem to be very promising [ 10$]$. There are reports in the literature about the possibility of using the concentration assessment of selected molecules in the diagnosis of AAA (Table I).

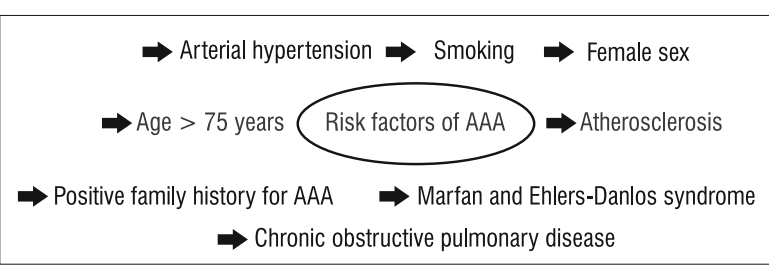

Figure I. Identified and putative risk factors of AAA

\section{Risk factors for AAA}

Numerous risk factors might contribute to AAA development (Fig. I). The most prominent are hypertension, smoking, male sex age $>75$ years, atherosclerosis, chronic obstructive pulmonary disease and positive family history for AAA including genetic background with gene mutations. Genetic predisposition is very important in assessing the risk of AAA. Results of studies revealed that AAA occurs in $25 \%$ of people who are relatives of the first degree to people with this disease. About $20 \%$ of people with AAA have genetic-based diseases, such as Marfan's or Ehlers-Danlos syndromes [19-23]. It is also worth to mention that smoking is a risk factor in developing this disease and every additional year of smoking increases the AAA risk by $4 \%$ [24].

\section{Anatomical and histological aspects of the abdominal aorta}

The abdominal aorta is formed due to the fusion of the two dorsal aortae in a caudo-cranial fashion. Congen- 
Table 2. Dimensions of abdominal aorta at different levels [25]

\begin{tabular}{|l|c|}
\hline Site & Diameter $(\mathrm{cm})$ \\
\hline Upper pole of left kidney & 7 \\
\hline $2 \mathrm{~cm}$ below origin of SMA & $7.2^{*}$ \\
\hline The lower pole of left kidney & 5.8 \\
\hline At the origin of IMA & 5.5 \\
\hline Just before bifurcation & $5.3^{*}$ \\
\hline
\end{tabular}

*Thickest; **Thinnest; SMA: superior mesenteric artery; IMA: inferior mesenteric artery

ital narrowing or coarctation of the aorta is primarily a defect of the tunica media, followed by proliferation of the tunica intima. Most of the changes in the caliber of abdominal aorta occur in later ages and are acquired. Tortuosity of abdominal aorta may be considered as a geometrical risk factor in the development of the abdominal aortic aneurysm. Abdominal aorta has a tendency to develop tortuosity with age due to loss of longitudinal stiffness [25].

The caliber of the abdominal aorta decreases downwards. According to cadaveric research (Fig. 2) by Mandal et al. [25], there were noticed dimensions of the abdominal aorta at its different levels (Table 2). The relation between aortic size and shape can probably be a factor contributing to the development of AAA [25-27]. Knowing the diameters, thickness and tortuosity of the abdominal aorta and their linkage to the danger of aneurysm and rupture are very important for clinicians and vascular surgeons [25]. According to Liu et al. [28], the arterial buckling could be a possible mechanism for the initiation of tortuous shape. The experimental studies revealed that under pulsatile pressure, the arteries buckled when the peak pressures were roughly equal to the critical buckling pressures under static pressure [27]. The stability of blood vessels under the lumen blood pressure is essential to the maintenance of normal arterial functioning [23]. Han [28] reported that arteries could buckle due to high blood pressure or low axial tension. Therefore, the residual stress in the arteries increases the buckling pressure. At junctions, such as the aortic bifurcation, transferred pressure waves may weaken the inner layer. The difference in luminal diameters of common iliac arteries may initiate turbulence in blood flow, damaging the intimal lining of the distal abdominal aorta [24, 25, 28]. The rupture of abdominal aortic aneurysm occurs when the mechanical stress acting on the inner wall, due to intraluminal pressure, exceeds the failure strength of the degenerated aortic tissue $[29,30]$.

\section{Pathophysiological mechanisms of abdominal aorta development}

The reason for the initiation of degradation changes in the blood vessel wall is poorly understood. Numerous factors are proposed to be involved at different stages of aneurysm development (Fig. 3). An abdominal aortic aneurysm is the final result of irreversible pathological remodelling of the extracellular matrix (ECM) [3I, 32]. ECMs ensure a relevant mechanical environment to which vascular tissue is continuously exposed. The main building blocks of the aortic wall are elastin and collagens [ $3 \mathrm{I}]$. On the contrary to elastin, which is a stable protein having half-life time measured in tens of years, collagens are normally remodelled by means of their continues deposition and degradation [32, 33].

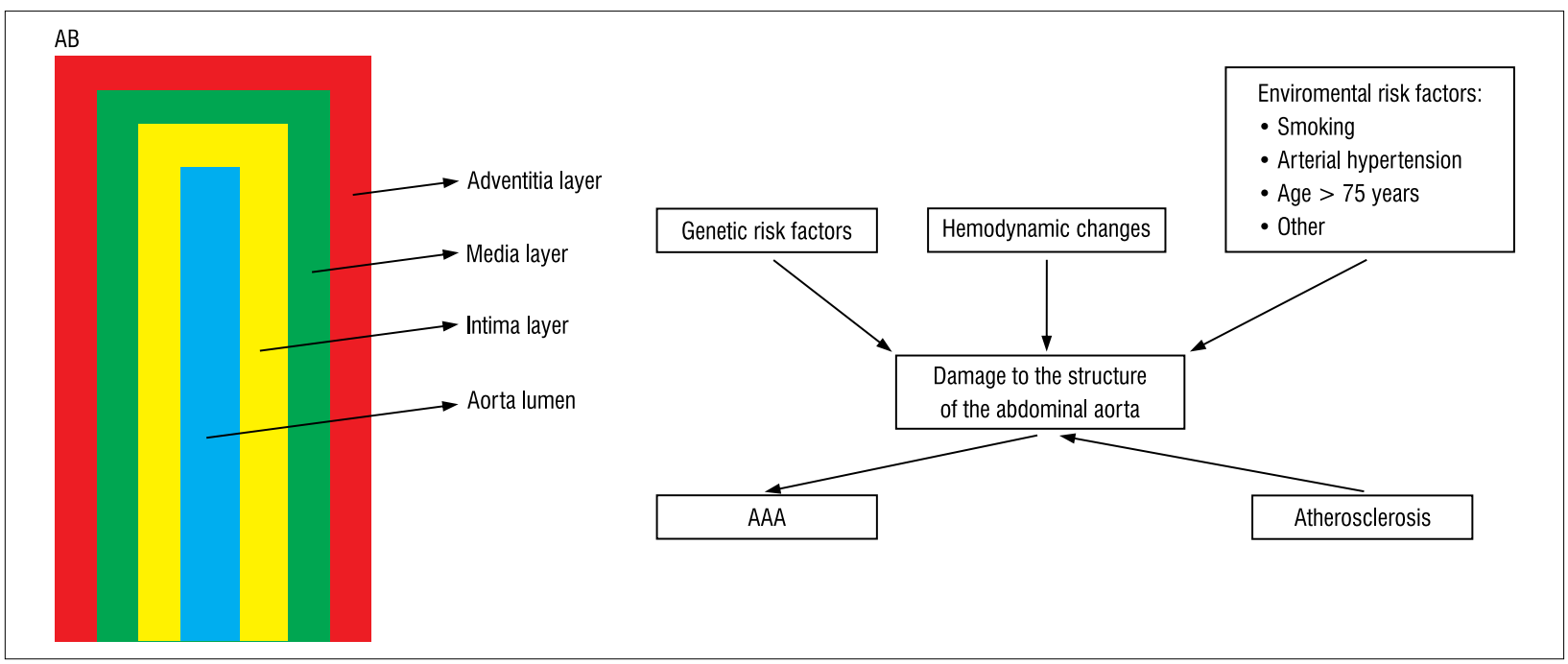

Figure 3. A - schematic construction of the aortic wall; B — pathological pathways of AAA development [32-38] 
Vascular collagens have a half-life time of 60-70 days under physiological conditions, which decreases by up to 10 -fold in case of disease and injury [34, 35]. The rupture of AAA occurs when the mechanical stress acting on the inner wall, due to intraluminal pressure, exceeds the failure strength of the degenerated aortic tissue [36].

Changes leading to the damage to the vessel wall relate to degradation of wall building components and the presence of inflammation within its walls. Under the influence of a damaging factor or as a result of induction with substances coming from disintegrating cells, cells present in the vascular wall such as macrophages, lymphocytes or smooth muscle cells produce cytokines and inflammatory mediators that are involved in the formation, as well as regulation of proteolytic enzymes responsible for the destruction of the abdominal aorta's wall. Activated lymphocytes producing interleukin-2 (IL-2), tumour necrosis factor alpha (TNF- $\alpha$ ) and interferon gamma (INF- $\gamma$ ) increase the proteolytic activity of macrophages. These macrophages are in turn a source of metalloproteases, responsible for the digestion of elastin, collagens, fibronectin, lamina and proteoglycans [15, 37-40]. The reduced content of elastin, as well as collagens and fibronectin, is a potential source of loss of elastic as well as mechanical properties of the aorta, thus, increasing the vessel diameter and creating a baggy dilation, called aneurysm [15]. Maintaining the proteolytic homeostasis protects the structural proteins of the aortic wall from degradation. Shifting this balance in the favour of proteinases causes uncontrolled degradation of these proteins and leads to the formation, the enlargement and the aneurysm rupture [4I, 42]. Frequent coexistence in patients with atherosclerotic TAB the coronary artery disease (CAD) and/or peripheral vascular disease (PAD) suggests the involvement of atherosclerotic lesions in increasing the risk of developing this disease. Some authors proposed that the abdominal aortic aneurysm is some kind of atherosclerosis [43]. Previous research results indicate that in the development of an abdominal aortic aneurysm, a major inflammatory reaction combined with tissue proteolysis, which results in the destruction and reconstruction of the blood vessel wall, is of key importance. However, much of the controversy results from the nature of the cellular response and the type of factors modulating the inflammatory response [44, 45].

\section{A role of homocysteine in the creation of abdominal aorta aneurysm}

Homocysteine is a thiol amino acid formed in all cells in the methionine - cysteine pathway. Its normal concentration in blood should not exceed $14 \mathrm{~mol} / \mathrm{l}$ on an empty stomach and 30 to $38 \mathrm{~mol} / \mathrm{l}$ after 6 hours from methionine loading [ $\mathrm{II}]$. Mild hyperhomocysteinemia occurs in approximately 5 to $7 \%$ of the population, whereas a significantly elevated level of this amino acid in the blood is observed in $20-40 \%$ of people suffering from cardiovascular disease [46]. Studies revealed that elevated levels of homocysteine occur in about $50 \%$ of people with AAA [47]. The main mechanisms leading to the development of AAA are inflammation within the vessel wall, degradation of connective tissue elements (elastin, collagens), mechanical injuries and genetic predisposition. Thus, the homocysteine presence at abnormal concentrations might affect any of the listed pathogenic mechanisms of AAA [48].

Elevated levels of homocysteine in the blood have toxic effects on the endothelium of blood vessels. Hyperhomocysteinemia activates the enzyme called asymmetric dimethylarginine (ADMA), which is an inhibitor of the endothelial isoform of nitric oxide synthase (eNOS) (Fig. 4). The reduction in eNOS activity results in a decrease in NO concentration, which impairs the vasodilating capacity of vascular endothelial cells [49]. Decreasing NO concentration leads to disturbance of a balance between vasodilating abilities in favour of vasoconstriction capacity. Proteolytic capacity increases and the concentrations of prostaglandin $\mathrm{G} 2\left(\mathrm{PGI}_{2}\right)$ are reduced, while the production of endothelin I (ET-I), angiotensin II, thromboxane A2 (TXA2) increases (Fig. 4). Hyperhomocysteinemia leads to impaired hemostasis (Fig. 4) resulting in the formation of a blood clot in the walls of the blood vessels. The impairment of vascular endothelial anticoagulant function is the basic pathogenic mechanism of AAA development [50]. Methyltetrahydrofolate reductase (MTHFR) is an enzyme responsible

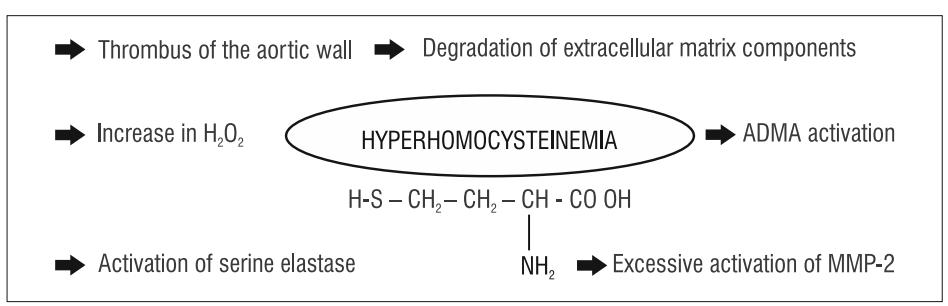

Figure 4. Pathophysiological consequences of hyperhomocysteinemia [49-5I] 
for the re-methylation of homocysteine to methionine, thereby lowering the homocysteine concentration. Results of studies have revealed that polymorphisms affecting the activity of this enzyme may occur within the MTHFR gene [5I-53]. The most frequent mutation in the MTHFR gene is the point mutation of the substitution of cytosine (c) for thymine (t) at position 677: $\mathrm{C} 677 \rightarrow \mathrm{T}$, resulting in the change Ala222 Val. As a result of this mutation, the enzyme N5-N10-methyltetrahydrofolate is formed, which is characterized by reduced activity, which promotes the development of hyperhomocysteinemia [53].

There is no doubt that hyperhomocysteinemia is the result of just having an effect on AAA [54]. Spark et al. [55] reported that the elevated concentration of this amino acid occurred in $53 \%$ of AAA subjects. However, these researchers did not show a relationship between the level of homocysteine concentration and the size of the abdominal aortic aneurysm. Brunelli et al. [56] proposed that in people with higher concentrations of homocysteine, the size of aneurysms was larger when compared to patients with a lower concentration of this amino acid. This is most likely related to the fact that an increased level of homocysteine leads to a thrombotic aortic clot, which makes access to extracellular matrix components difficult for enzymes degrading its components, such as elastin $[56,57]$.

\section{Roles of osteoprotegerin and osteopontin in the abdominal aorta aneurysm}

Osteoprotegerin is an osteoneogenesis-inhibiting factor, probably a calcification inhibitor, which prevents the formation of calcium deposits. Osteoprotegerin in combination with RANKL prevents the formation of the RANKL-RANK complex and thus blocks the activation of osteoclasts [58]. Osteopontin binds $\mathrm{Ca}^{2+}$ with high affinity and enhances bone resorption by coating hydroxyapatites by osteoclasts. It is an inhibitor of hydroxyapatite crystallization in vitro and inhibits the binding of the cell adhesion molecule with apatite (crystal growth). Osteopontin is produced by osteoclasts and is responsible for the adhesion of macrophages [59].

Numerous study reports have shown that both, osteopontin and osteoprotegerin are involved in the activation of immune system cells and exacerbate atherosclerotic lesions resulting from an increase in calcification of the walls of blood vessels [58-60]. In the study of patients with AAA and Leriche's syndrome, manifested by a set of symptoms caused by stenosis or obstruction of the final segment of the abdominal aorta and/or iliac arteries, higher concentrations of osteoprotegerin and osteopontin in the group with AAA were detected. The study also revealed that higher concentrations of osteopontin are characteristic in patients with AAA with concomitant coronary artery disease, while higher concentrations of osteoprotegerin are characteristic in patients with AAA after a stroke. There was no correlation between the level of osteoprotegerin and osteopontin concentration and the diameter of the abdominal aortic aneurysm. Moreover, a positive correlation between the concentration of osteopontin and C-reactive protein (CRP) has been detected, which confirms its pro-inflammatory nature [6I, 62].

\section{MicroRNAs in the abdominal aorta aneurysm}

MicroRNA 7I 2/205 (miR-7 I 2/205) is a tissue inhibitor of metalloproteinase-3 inhibitor (TIMP3). In the AAA mouse model, the concentration of the miR-7/2/205 was higher [63]. miR-7/2/205 also has an inhibitory effect on $\alpha 2$-macroglobulin, which is a membrane-anchored reversion-inducing-cysteine-rich glycoprotein (RECK), inhibiting the activity of MMP-9, MMP-2 and MMP-I 4 [64]. The increased concentration of miR$712 / 205$ leads through the inhibition of TIMP3 and RECK to the increased activity of MMPs, especially MMP3. The increased activity of MMPs leads to the development of inflammation and degradation of the connective tissue components within the aortic wall, which increases the risk of AAA development [65]. Elevated levels of miRNA 29c-3p in patients with AAA were reported by Lichołai et al. [13]. These researchers compared the serum composition of patients with AAA with the serum composition of patients without AAA found an increased concentration of mi-29c-3p, which correlated with the diameter of the aneurysm. Elevated concentration of miR-29c-3p in vitro led to the lower expression of genes such as elastin encoding gene $(E L N)$, the gene coding for collagen type IV alpha- I chain (COL4AI), the gene for phosphatase and tensin homolog (PTEN), a gene coding for vascular endothelial growth factors isoform $A$ (VEGFA). The results suggest that elevated miR-29c-3p is a potential serum biomarker for AAA because inhibition of genes encoding proteins of the vascular wall matrix components (aortas) leads to greater susceptibility to aneurysm development [13].

\section{Roles of interleukins 2, 6, I0 and c-reactive protein in the abdominal aorta aneurysm}

Interleukins are cytokines involved in immune and hematopoietic processes. As of today, several dozen proteins belonging to this group of compounds were described [66]. In the pathogenesis of AAA, interleukins 2, 6, 10 and C-reactive protein (CRP) appear to be the most important. CRP is one of the most important indi- 
cators of inflammation. It is produced in the liver under the influence of interleukin 6 [67]. Oszkinis et al. [4] analyzed the concentration of interleukins 2, 6, 10 and CRP in individuals without AAA and in patients with AAA. These researchers showed a statistically significant increase in interleukin 6 and CRP protein in subjects with AAA compared to those without AAA. In addition, there was a correlation between the level of interleukin 2, interleukin 6 and CRP protein and the diameter of the abdominal aortic aneurysm. In the group of patients with AAA, there was no statistically significant positive correlation between IL-I0 serum concentration and the aneurysm diameter. In the conclusions from this study, the researches stated that the serum cytokines IL-2, IL-6 and CRP are useful for monitoring the severity of inflammatory lesions responsible for the increase in the diameter of the aneurysm. With the change in size, the aneurysm increases the concentration of inflammatory proteins, which may indicate the dependence of the aneurysm widening on the severity of inflammatory processes and have a significant impact on the decision on surgical treatment [4].

\section{Roles of $\alpha_{1}$-antiproteinase, anti-thrombin III and cystatin C in the abdominal aorta aneurysm}

One of the main components of the AAA pathogenesis is the disturbance of the proteolytic and antipathetic balance [68-77]. In the case of AAA, there is an increase in proteolytic mechanisms towards antiproteolytic activity, which leads to enlargement and rupture of the aneurysm [78]. Proteinases are synthesized in cells of aortic walls, such as endothelial cells, myocytes and fibroblasts and in cells inflowing to the aortic wall of the aneurysm, mainly monocytes/macrophages, granulocytes, lymphocytes and mast cells. In the aneurysm wall, there are proteinases and proteinase inhibitors [77-79]. Gacko et al. [16] analyzed the activity of serine proteinase inhibitors (serpins) and the activity of cysteine proteinase inhibitors (cystatin) in diseases with AAA. The research group consisted of 15 people with AAA (mean age 65.3 years), while the control group consisted of 12 people without AAA at a similar age. The activity of inhibitors in the blood plasma was determined by measuring the degree of reduction of the specific activity of each proteinase, acting on a specific substrate. For the activity of inhibitors, the following were used: al-antiproteinase (al-AP) - trypsin and Cbz-DL-ArgpNA, al-antichymotrypsin $(\alpha \mathrm{I}-\mathrm{ACT})$ - chymotypsin and Cbz-Phe-pNA, $\alpha 2$-macroglobulin ( $\alpha 2-\mathrm{MG})-$ trypsin and $\mathrm{Cbz}-\mathrm{Val}-\mathrm{Gly}-\mathrm{Arg}-\mathrm{pNA}$, in the presence of a chiral route, $\alpha 2$-antiplasmin (a2-API) - plasmin and D-Val-Leu-Lys-pNA, antithrombin III (AT-III) - thrombin and fibrinogen, cystatin - papain and casein, after prior inactivation of $\alpha 2-M G$. These researchers showed that in plasma in patients with aortic aneurysm much higher activity of $\alpha$ I-AP than in healthy subjects, the activity of $\alpha$ I-ACT, $\alpha 2-M G$ and $\alpha 2$-API did not differ in the compared groups. However, AT-III activity and cystatin $\mathrm{C}$ activity in the blood plasma in patients with aortic aneurysm remained lower than in healthy subjects. In the results of the study, the authors state that the abdominal aortic aneurysm is accompanied by systemic reaction manifested by increased activity and concentration of $\alpha$ I-AP, decreased activity and AT-III concentration and decreased activity and concentration. cystatins in blood plasma. This indicates a proteinase - antiproteinase imbalance and the activation of blood coagulation in patients with aortic aneurysm [16].

\section{Transcription factors are potentially involved in the abdominal aorta aneurysm}

In the course of AAA pathological expression of many proteins was observed, including transcription factors such as ELFI, ETS2, RUNXI, STAT5. Pahl et al. [17] evaluated the level of selected transcription factors in individuals with AAA and compared them with samples obtained from people without AAA. These researchers showed that the concentration of ELFI is 1.8 fold higher in people with AAA compared to healthy subjects. The concentration of ETS2 factor was elevated I. 4 times, while the RUNXI factor was 2.5 fold higher. There were no differences in the STAT factor [17]. ELFI, ETS2, RUNXI and STAT5 transcription factors are important regulators of immune cell proliferation, differentiation and activation [80-83]. Researchers investigated the target genes of these transcription factors by the use the Gene Ontology (GO) biological function categories. The data revealed that in the AAA tissue most significantly enriched biological function categories were leukocyte migration and intracellular protein kinase cascade [17] In the control aorta, the most significant GO categories differed from those in the AAA samples and included cytoskeleton organization and small GTPase mediated signal transduction. The genes up-regulated in AAA tissue showed highly significant enrichment for Gene Ontology categories leukocyte migration, activation of the immune response, $\mathrm{T}$ cell activation and regulation of lymphocyte activation [ 17].

The genes downregulated in AAA were enriched in completely different GO categories including cytoskeleton organization, muscle cell development, organ morphogenesis and cell junction assembly [17]. The data provide evidence for the involvement of the immune system in the pathogenesis of AAA and indicate that ELFI, ETS2, RUNXI and STAT5 transcriptional factors may be very important agents in this process. 


\section{Summary}

Many factors are involved in the pathogenesis of AAA: proteins, transcription factors, enzymes, and microRNAs. The increase in the concentration of most factors is associated with inflammation. Inflammation is the main mechanism leading to the development of AAA but also other diseases such as atherosclerosis, diabetes mellitus, hypertension, rheumatoid arthritis, etc. The biomarkers presented in this paper are not restricted to $A A A$, and therefore can only be used for an illustrative assessment of the degree of abdominal aortic aneurysm development. As of today, radiological tests are the only fully reliable tests that can be used to diagnose AAA.

\section{Conflict of interest}

None.

\section{References:}

I. Siwko A, Hendiger W, Eberhardt A, et al. Parametryzacja wymiarów tętniaków aorty brzusznej w materiale Kliniki Chirurgii Naczyniowej i Angiologii Centrum Medycznego Kształcenia Podyplomowego Szpitala Bielańskiego w Warszawie. Post N Med. 2016; XXIX(IIB): 2I-24.

2. Johnston KW, Rutherford RB, Tilson MD, et al. Suggested standards for reporting on arterial aneurysms. Subcommittee on Reporting Standards for Arterial Aneurysms, Ad Hoc Committee on Reporting Standards, Society for Vascular Surgery and North American Chapter, International Society for Cardiovascular Surgery. J Vasc Surg. 1991; 13(3): 452-458, indexed in Pubmed: 1999868.

3. Cameron JL. Current surgical therapy. 7th ed. Mosby, St Louis 200I: 807-812.

4. Oszkinis G. Znaczenie czynnika zapalnego w patogenezie tętniaka aorty brzusznej; praca habilitacyjna, AM w Poznaniu, 2000, II-12; 54-56; 60-122.

5. Kent KC. Clinical practice. Abdominal aortic aneurysms. N Engl J Med. 2014; 37I (22): 210I-2108, doi: 10.1056/NEJMcp I40 I430, indexed in Pubmed: 25427। I 2.

6. Karwowska A, Kurianiuk A, Łapiński R. Epidemiology of abdominal aortic aneurysm. Prog Health Sci . 2015; 5(I): 238-245.

7. Barratt-Boyes BG. Symptomatology and prognosis of abdominal aortic aneurysm. The Lancet. 1957; 270(6998): 716-159, doi: 720.

8. Millar AJ, Gilbert RD, Brown RA, et al. Abdominal aortic aneurysms in children. J Pediatr Surg. 1996; 31(12): 1624-1628, indexed in Pubmed: 8986973.

9. http://www.mp.pl/interna/chapter/B I6.II.2.22. (4.01.2019).

10. Frómankiewicz B, Jawień A. Rola badań przesiewowych we wczesnym wykrywaniu tętniaka aorty brzusznej. Acta Angiol. 2012; I8(I): I-8.

II. Siennicka A, Jastrzębska M. Rola homocysteiny w patogenezie tętniaka aorty brzusznej. Journal of Laboratory Diagnostics. 20I2; 48(4): 413-422.
12. Czyżewska - Bu, Żuk N, Bałasz S, et al. Ocena stężenia osteopontyny i osteoprotegryny u chorych $z$ tętniakiem aorty brzusznej. Przegląd Lekarski. 2013; 70(3): 102-105.

13. Licholai S, Szczeklik W, Sanak M. miR-29c-3p is an Effective Biomarker of Abdominal Aortic Aneurysm in Patients Undergoing Elective Surgery. Microrna. 2016; 5(2): 124-13|, indexed in Pubmed: 27585857.

14. Maegdefessel L, Spin JM, Tsao PS. New ways to dismantle a ticking time bomb: microRNA 7/2/205 and abdominal aortic aneurysm development. Arterioscler Thromb Vasc Biol. 2014; 34(7): 1339-1340, doi: 10.1 161/ATVBAHA. I 4.303952, indexed in Pubmed: 24951652.

15. Oszkinis G, Kamiński J, Gabriel M, et al. Wartość oznaczania cytokin prozapalnych oraz zmian ilościowych białka ostrej fazy u chorych z tętniakiem aorty brzusznej. Chirurgia Polska. 2007; 9(4): 223-230.

16. Gacko M, Łapiński R, Guzowski A, et al. Aktywność i stężenie inhibitorów proteinaz osocza krwi chorych z tętniakiem aorty brzusznej. Chirurgia Polska. 2003; 5(4): 189-193.

17. Pahl MC, Erdman R, Kuivaniemi H, et al. Transcriptional (ChIPChip) Analysis of ELFI, ETS2, RUNXI and STAT5 in Human Abdominal Aortic Aneurysm. Int J Mol Sci. 2015; 16(5): I 1229 I 1258, doi: 10.3390/ijms/605/1229, indexed in Pubmed: 25993293.

18. Choke E, Cockerill G, Wilson WRW, et al. A review of biological factors implicated in abdominal aortic aneurysm rupture. Eur J Vasc Endovasc Surg. 2005; 30(3): 227-244, doi: 10.1016/j. ejvs.2005.03.009, indexed in Pubmed: I5893484.

19. Januszewicz W, Grodzicki T, Sitkowska-Janaszek H, et al. Nadciśnienie tętnicze - czynnik ryzyka rozwoju tętniaka aorty brzusznej. Arterial Hypertension. 2005; 9(6): 469-473.

20. Ailawadi G, Eliason JL, Upchurch GR. Current concepts in the pathogenesis of abdominal aortic aneurysm. J Vasc Surg. 2003; 38(3): 584-588, indexed in Pubmed: 12947280.

21. Guzik B, Ignacak A, Anders M, et al. Czynniki ryzyka i etiopatogeneza tętniaków aorty brzusznej. Czynniki Ryzyka. 2012; I: 6-16.

22. Refsum $H$, Smith AD, Ueland PM, et al. Facts and recommendations about total homocysteine determinations: an expert opinion. Clin Chem. 2004; 50(I): 3-32, doi: 10.1373/ clinchem.2003.021634, indexed in Pubmed: 14709635.

23. Piotrkowska R, Landowska A, Książek J, et al. Methods for surgical treatment of abdominal aortic aneurysm - therapeutic and nursing implications. Medycyna Rodzinna. 2015; I: 28-33.

24. Szmidt J, Jakimowicz T. Postępy w leczeniu tętniaków aorty brzusznej. Postępy Nauk Medycznych. 2012; I: 37-43.

25. Mandal L, Mukhopadhyay P, Roy T, et al. Impact and biomechanical mechanisms of tortuosity of abdominal aorta - a case report. Natl J Med Res. 2016; 6(2): 219-22I.

26. Lopamudra M, Paramita M, Tapati R, et al. Impact and biomechanical mechanisms of tortuosity of abdominal aorta - a case report. NJ Medical Research. 2016; 6(2): 219-221.

27. Newman DL, Gosling RG, Bowden NL. Changes in aortic distensibility and area ratio with the development of atherosclerosis. Atherosclerosis. 1971; 14(2): 231-240, indexed in Pubmed: 5118614.

28. Liu Q, Han HC. Mechanical buckling of artery under pulsatile pressure. J Biomech. 2012; 45(7): I192-1198, doi: 10.1016/j. jbiomech.2012.01.035, indexed in Pubmed: 22356844. 
29. Han HC. Nonlinear buckling of blood vessels: a theoretical study. J Biomech. 2008; 4I (I2): 2708-27I3, doi: 10.1016/j.jbiomech.2008.06.012, indexed in Pubmed: I8653191.

30. Marfuni G. Biomechanism of abdominal aortic aneurysym: Experimental evidence and multiscale constitutive modeling. Doctoral thesis no. $80 \mathrm{KTH}$ School of Engineering Sciences Department of Solid Mechanics Royal Institute of Technology SE-100 44 Stockholm Sweden. : 2012.

31. Davies MJ. Aortic aneurysm formation: lessons from human studies and experimental models. Circulation. 1998; 98(3): 193-195, indexed in Pubmed: 9697816.

32. Carey DJ. Control of growth and differentiation of vascular cells by extracellular matrix proteins. Annu Rev Physiol. 1991; 53: 161-177, doi: 10.1 146/annurev.ph.53.030191.001113, indexed in Pubmed: 2042957.

33. Alberts B, Bray D, Lewis J, Raff M, Roberts K, Watson JD. Molecular biology of the cell. Garland Publishing, Ypsilanti 1994: Garland.

34. Humphrey JD. Remodeling of a collagenous tissue at fixed lengths. J Biomech Eng. 1999; 121(6): 591-597, indexed in Pubmed: 10633258.

35. Nissen R, Cardinale GJ, Udenfriend S. Increased turnover of arterial collagen in hypertensive rats. Proc Natl Acad Sci U S A. 1978; 75(I): 45I-453, indexed in Pubmed: 272662.

36. Bashey RI, Cox R, McCann J, et al. Changes in collagen biosynthesis, types, and mechanics of aorta in hypertensive rats. J Lab Clin Med. 1989; I I3(5): 604-6 I I, indexed in Pubmed: 27 I 5682.

37. Vorp DA, Raghavan ML, Webster MW. Mechanical wall stress in abdominal aortic aneurysm: influence of diameter and asymmetry. J Vasc Surg. 1998; 27(4): 632-639, indexed in Pubmed: 9576075.

38. Berillis P. The Role of Collagen in the Aorta's Structure. The Open Circulation and Vascular Journal. 2013; 6(I): 1-8, doi: 10.2174/I87738260I3060I000I.

39. Holmes DR, Liao S, Parks WC, et al. Medial neovascularization in abdominal aortic aneurysms: a histopathologic marker of aneurysmal degeneration with pathophysiologic implications. J Vasc Surg. 1995; 2I(5): 76I-7I; discussion 77I, indexed in Pubmed: 7539511 .

40. Juvonen J, Surcel HM, Satta J, et al. Elevated circulating levels of inflammatory cytokines in patients with abdominal aortic aneurysm. Arterioscler Thromb Vasc Biol. 1997; I7(II): 2843-2847, indexed in Pubmed: 9409264.

4I. Jones KG, Brull DJ, Brown LC, et al. Interleukin-6 (IL-6) and the prognosis of abdominal aortic aneurysms. Circulation. 200I; 103(I8): 2260-2265, indexed in Pubmed: I I342474.

42. Tamarina NA, McMillan WD, Shively VP, et al. Expression of matrix metalloproteinases and their inhibitors in aneurysms and normal aorta. Surgery. 1997; 122(2): 264-7I; discussion 27I, indexed in Pubmed: 9288131.

43. Thompson RW, Parks WC. Role of matrix metalloproteinases in abdominal aortic aneurysms. Ann N Y Acad Sci. 1996; 800: 157-174, indexed in Pubmed: 8958991.

44. Tilson MD. Aortic aneurysms and atherosclerosis. Circulation. 1992; 85(I): 378-379, doi: 10.1161/01.cir.85.1.378.

45. Blake GJ, Ridker PM. Novel clinical markers of vascular wall inflammation. Circ Res. 200I; 89(9): 763-77I, indexed in Pubmed: 11679405.

46. Ailawadi G, Eliason JL, Upchurch GR. Current concepts in the pathogenesis of abdominal aortic aneurysm. J Vasc Surg. 2003; 38(3): 584-588, indexed in Pubmed: 12947280.
47. Naruszewicz M. Aktualne spojrzenie na rolę hiperhomocysteinemii w patogenezie miażdżycy. Pol Prz Neurol. 2005; I(I): 19-22.

48. Costantino TG, Bruno EC, Handly N, et al. Accuracy of emergency medicine ultrasound in the evaluation of abdominal aortic aneurysm. J Emerg Med. 2005; 29(4): 455-460, doi: 10.1016/j. jemermed.2005.02.016, indexed in Pubmed: 16243207.

49. Wassef M, Baxter BT, Chisholm RL, et al. Pathogenesis of abdominal aortic aneurysms: a multidisciplinary research program supported by the National Heart, Lung, and Blood Institute. J Vasc Surg. 200I; 34(4): 730-738, doi: 10.1067/mva.200I.I16966, indexed in Pubmed: II66833।.

50. Kraczkowska S, Suchocka Z, Pachecki J. Podwyższone stężenie homocysteiny we krwi jako wskaźnik zagrożenia zdrowia. Biul Wydz Farm AMW. 2005; 3: 4-13.

5I. Li JJ, Fang $\mathrm{CH}$. Atheroscleritis is a more rational term for the pathological entity currently known as atherosclerosis. Med Hypotheses. 2004; 63(1): 100-102, doi: 10.1016/j. mehy.2004.01.029, indexed in Pubmed: 15193358.

52. Ferrara F, Novo S, Grimaudo S, et al. Methylenetetrahydrofolate reductase mutation in subjects with abdominal aortic aneurysm subdivided for age. Clin Hemorheol Microcirc. 2006; 34(3): 42I-426, indexed in Pubmed: $166 \mid 4466$.

53. Palko-Łabuz A, Sadakierska-Chudy A, Pilecki W. The genetic background of thrombosis - the distributions of factor $\mathrm{V}$ Leiden, prothrombin G20210A, and MTHFR C677T polymorphisms. Adv Clin Exp Med. 2010; 19: 51-55.

54. Cao H, Hu X, Zhang Q, et al. Homocysteine level and risk of abdominal aortic aneurysm: a meta-analysis. PLoS One. 2014; 9(I): e85831, doi: 10.1371/journal.pone.008583।, indexed in Pubmed: 24465733.

55. Spark Jl, Laws P, Fitridge R. The incidence of hyperhomocysteinaemia in vascular patients. Eur J Vasc Endovasc Surg. 2003; 26(5): 558-56।.

56. Brunelli T, Prisco D, Fedi S, et al. High prevalence of mild hyperhomocysteinemia in patients with abdominal aortic aneurysm. J Vasc Surg. 2000; 32(3): 531-536, doi: 10.1067/ mva.2000.107563, indexed in Pubmed: 10957660.

57. Millo B, Wiernicki I, Bukowska H, et al. 2P-0380 Serum homocysteine and MCP-I are associated with abdominal aortic aneurysm size and interluminal thrombus dimension. Atherosclerosis Supplements. 2003; 4(2): 122, doi: 10.1016/s15675688(03)90523-x.

58. Schoppet M, Preissner KT, Hofbauer LC. RANK ligand and osteoprotegerin: paracrine regulators of bone metabolism and vascular function. Arterioscler Thromb Vasc Biol. 2002; 22(4): 549-553, indexed in Pubmed: I 1950689.

59. Demer LL, Tintut Y. Mechanisms linking osteoprosis and cardiovascular calcification. Curr Osteoporos Rep. 2009; 7(2): 42-46.

60. Knudsen ST, Foss CH, Poulsen PL, et al. Increased plasma concentrations of osteoprotegerin in type 2 diabetic patients with microvascular complications. Eur J Endocrinol. 2003; 149(1): 39-42, indexed in Pubmed: 12824864.

61. Nagasaka A, Matsue H, Matsushima H, et al. Osteopontin is produced by mast cells and affects lgE-mediated degranulation and migration of mast cells. Eur J Immunol. 2008; 38(2): 489-499, doi: 10.1002/eji.200737057, indexed in Pubmed: 18200503.

62. Witkiewicz W, Czyżewska-Buczyńska A, Bałasz S, et al. Rola osteopontyny w chorobach sercowo-naczyniowych. Pol Merk Lek. 2010; 170: 79. 
63. Kim CW, Kumar S, Son DJu, et al. Prevention of abdominal aortic aneurysm by anti-microRNA-7 12 or anti-microRNA-205 in angiotensin II-infused mice. Arterioscler Thromb Vasc Biol. 2014; 34(7): 1412-1421, doi: 10.1 I6I/ATVBAHA. I 13.303134, indexed in Pubmed: 248I 2324.

64. Jung P, Zimowska M. Metaloproteinazy macierzy zewnątrzkomórkowej w rozwoju, fizjologii i procesach degeneracyjnych mięśni szkieletowych. Postępy Biochemii. 2016; I(62): 25-35.

65. Boon RA, Seeger T, Heydt S, et al. MicroRNA-29 in aortic dilation: implications for aneurysm formation. Circ Res. 201 I; 109(10): III5-II19, doi: 10.1 16I/CIRCRESAHA. I I1.255737, indexed in Pubmed: 21903938.

66. Tokarz-Deptuła B, Miller T, Deptuła W. Cytokiny z rodziny interleukiny I. Post Mikrobiol. 20I I; 50(3): 217-22I.

67. Marnell L, Mold C, Du Clos TW. C-reactive protein: ligands, receptors and role in inflammation. Clin Immunol. 2005; I I7(2): 104-I I I, doi: 10.1016/j.clim.2005.08.004, indexed in Pubmed: 16214080.

68. Crowther M, Goodall S, Jones JL, et al. Increased matrix metalloproteinase 2 expression in vascular smooth muscle cells cultured from abdominal aortic aneurysms. J Vasc Surg. 2000; 32(3): 575-583, doi: 10.1067/mva.2000. 108010 , indexed in Pubmed: 10957667.

69. Gacko M, Chyczewski L, Chrostek L. Distribution, activity and concentration of cathepsin $B$ and cystatin $C$ in the wall of aortic aneurysm. Pol J Pathol. 1999; 50(2): 83-86, indexed in Pubmed: 1048I53I.

70. Gacko M, Worowska A, Głowiński S. Aktywność proteolityczna i antyproteolityczna ściany tętniaka i aorty zmienionej miażdżycowo. Pamiętnik 56 Zjazd Tow. Chir. Pol., Lublin 1993; 4: 1632-1635. 1993.

7I. Jean-Claude J, Newman KM, Li H, et al. Possible key role for plasmin in the pathogenesis of abdominal aortic aneurysms. Surgery. 1994; II6(2): 472-478, indexed in Pubmed: 80480I3.

72. Lindholt JS, Erlandsen EJ, Henneberg EW. Cystatin C deficiency is associated with the progression of small abdominal aortic aneurysms. Br J Surg. 200 I; 88(I I): I472-I475, doi: 10.1046/j.00071323.2001.0191 I.x, indexed in Pubmed: I | 683743.

73. Shah P. Inflammation, Metalloproteinases, and Increased Proteolysis. Circulation. 1997; 96(7): 2115-2117, doi: 10.1161/01. cir.96.7.2115.
74. Skóra J, Janczak D, Barć P, et al. Badanie poziomu elastyny w ścianie tętniaków aorty brzusznej. Pol Merk Lek. 2000; 9 : 552-553.

75. Tamarina NA, McMillan WD, Shively VP, et al. Expression of matrix metalloproteinases and their inhibitors in aneurysms and normal aorta. Surgery. 1997; 122(2): 264-27I, indexed in Pubmed: 9288|3।.

76. Thompson RW, Parks WC. Role of matrix metalloproteinases in abdominal aortic aneurysms. Ann N Y Acad Sci. 1996; 800: 157-174, indexed in Pubmed: 895899I.

77. Badmer JL, Schnebli HP. Plasma proteinase inhibitors. Schweiz Med Wsch. 1984; I 14: 1359-1363.

78. Ikari Y, Mulvihill E, Schwartz SM. alpha I-Proteinase inhibitor, alpha I-antichymotrypsin, and alpha 2-macroglobulin are the antiapoptotic factors of vascular smooth muscle cells. J Biol Chem. 200I; 276(I5): II798-II803, doi: 10.1074/jbc.M008503200, indexed in Pubmed: 11096092.

79. Lindholt JS, Jørgensen B, Fasting $\mathrm{H}$, et al. Plasma levels of plasmin-antiplasmin-complexes are predictive for small abdominal aortic aneurysms expanding to operation-recommendable sizes. J Vasc Surg. 200I; 34(4): 6II-6I5, doi: 10.1067/ mva.200I.I 19040, indexed in Pubmed: I I6683 I 3.

80. Hinterseher I, Erdman R, Donoso LA, et al. Role of complement cascade in abdominal aortic aneurysms. Arterioscler Thromb Vasc Biol. 2011; 31(7): 1653-1660, doi: 10.1161/ATVBAHA. II I.227652, indexed in Pubmed: 21493888.

8I. Gallant S, Gilkeson G. ETS transcription factors and regulation of immunity. Arch Immunol Ther Exp (Warsz). 2006; 54(3): 149-163, doi: 10.1007/s00005-006-0017-z, indexed in Pubmed: 16652219.

82. Nottingham WT, Jarratt A, Burgess $M$, et al. RunxI-mediated hematopoietic stem-cell emergence is controlled by a Gata/ Ets/SCL-regulated enhancer. Blood. 2007; I I0(I3): 4188-4197, doi: 10.1182/blood-2007-07-100883, indexed in Pubmed: 17823307.

83. Mahmud SA, Manlove LS, Farrar MA. Interleukin-2 and STAT5 in regulatory T cell development and function. JAKSTAT. 2013; 2(I): e23154, doi: $10.4161 /$ jkst.23154, indexed in Pubmed: 24058794. 